\title{
From Garden City to Smart Growth: The Evolution and Management of New Urbanism
}

\author{
Chen Youzhen ${ }^{1}$, Duan Longlong ${ }^{2}$ \\ ${ }^{1,2}$ School of Public Administration, Southwest Jiaotong University, \\ Chengdu, P.R.China, 610031 \\ (E-mail: cyouzhen@126.com, duanlonglong2006@126.com)
}

\begin{abstract}
Under the influence of industrialization and rapid population growth after World War II, urban sprawl, central cities' recession and metropolis diseases have become three tumors that restricted urban sustainable development in western countries, so the new urbanism has arisen. From garden city to smart growth, new urbanism thoughts have experienced long-term evolution. Diversification, compactness, public transportation and social integration advocated by new urbanism have been supported by the majority of people. The paper illustrates, in detail, the evolution and management of new urbanism.
\end{abstract}

Key words Garden city; Smart Growth; Evolution; Management; New Urbanism

\section{Introduction}

Industrial revolution and economic globalization have been the two most important factors affecting the evolution of city forms since the 19th century. International flows of capital, technical progress and a series of material civilization transmutation make continuous decomposition and reconstruction in city scale and urban space forms in many countries. Dominated by new liberalism and laissez-faire planning thoughts, urban sprawl, suburbanization and de-urbanization become three characteristics of urban space forms in contemporary western countries. [1] The car-oriented transit mode produced in industrial city leads to over-exploitation of abundant urban lands and poses a challenge to the safety and ecological protection of central cities. Suburbanization, on one hand, caused central cities' recession increased the difficulties of urban regeneration; and on the other hand, accelerated social exclusion and class polarization along with the presence of gated communities in suburbs, bringing more fragmentation in urban spaces. Distinguished by low density development and scattered distribution, suburbanization caused many problems of the privatization of public spaces the embezzlement of lots of urban lands and the acceleration of social contradiction and social isolation, so the rectification of suburbanization and the containment of urban sprawl have become core issues of urban development in main western countries since mid-20th century.

The great discussion about "challenges to urban sprawl" has continued for nearly half a century, but there have not been many agreements on inter-cultural universal measures. In geography and ekistics, the scholars have their own opinions, but hold a doubtful attitude to the others' solutions. Even in the academic circle of geography, scholars in North American and Europe hold different opinions, and their main disputes concern two space forms of urban sustainable development, namely dispersion or compactness[2]. Firstly we need to make it clear that compact space form of city is certain; here dispersion or compactness just mean two forms of compact city, i.e.multiple-centers or single-center. Based on the specific practices of the two space forms, a series of ideas about urban forms have arisen. New urbanism is one of them. It includes new modes of urban forms and development, learns experience from numerous thoughts and urban development practices, affirms compact forms, advocates mixed-used and diversified urban transit modes. It builds self-included community, creates clear urban landmarks and opposes car-oriented extensive development. Because new urbanism brings nice community vision to citizens and local governments, it has become a successful 
example among numerous thoughts about urban form development [3].

\section{The origin of new urbanism: wrestle between theories and practices}

As the outcome of both theory and practice, new urbanism thoughts widely exist in the western countries nowadays. New urbanism tend to express itself more in practice than in theory, which is determined by its first spread in ekistics, so to seek the origin of new urbanism needs to examine both the theory and the practice.

First, in practice, new urbanism traces back to the "Pruitt-Ego" high public residence in Saint Louis in 1972. Also it may date back to 2500 B.C. in Indian Valley. A lot of urban characteristics at that time, such as mixed uses, small blocks and walk-oriented modes, are applied in new urbanism now. In theory, scholars on new urbanism universally take Camillo Sitte's works The Urban Design Depends on Its Artistic Principle published in 1989 , as the origin of new urbanism. In his book, Sitte opposes straightforward avenues designed by the Europeans and encourages people to apply architectural principles of European medieval. Just from this point of view, new urbanism tends to advocate cross mergings of tradition and modernity. [4]

Although Sitte's works, to a great extent, is regarded as the origin of new urbanism, his works contributes little to the spread of new urbanism concerning theoretical construction. In coomparison, Jane Jacobs' works The Life and Death of Great American Cities (1961) does the most theoretical contribution to new urbanism. Jane Jacobs holds the opinion that the vitality of the city comes from the density, mixed uses and diversified neighborhoods, so he opposes to built high-rise buildings and large parks because they aggravate crimes and social isolation. Good cities and neighborhoods must be committed to connect people from different sectors [5]. Based on this theory and combined with the tendencies in 1970s such as compact urban forms, historical architecture renewal, urban revitalization and mixed division, new urbanism clearly puts forward integrated theories about different forms of urban development, and the theoretical paradigm of new urbanism was established.

In fact, even the scholars of new urbanism admit that when people try to find the origin both in theory and in practice there exist different judge standards. New urbanism is an outcome of historical, experience and references. Howard's garden city theory, Perry's neighbor unit's theory and urban regeneration theory of Site promote the evolution of new urbanism. [6]

\section{From Garden City to Smart Growth: the Evolution and Management}

Historically, the concept and planning ideas of Garden City has a big impact on the formation and evolution of the subsequent new urbanism. Even after a-century-long changes, the essence of the Garden City concepts has affected much the thoughts of the contemporary new urbanism. After Garden City, the school of revisionism appeals to improve the designs of Garden City and to develop the suburban areas of the city. In 1920s and 1930s, they put forward modes such as "Neighborhood Units" and "Sunshine Cities", in an attempt to expand the values of Garden City by connecting the suburbanization development with compact layouts, good public spaces and emphasis on ecological balance in the thoughts of Garden City. They also intended to evolve the idealistic mode of Howard to the suburban development mode. Owing to these concepts, the revisionist school has become the main driver of the urban sprawl and the suburbanization movement. [7] It was not until 1980s when people from all walks of life fiercely criticized the suburban sprawl and the metropolitan diseases that the revisionists' rights of discourse was deprived, which made new urbanism, which advocates to curb the sprawl and to construct the real harmonious community, step on the stage of history.

\subsection{Garden City: Origin of New Urbanism}

The concept of Garden City was brought up under the background where the recession of central cities and the suburbanization coexisted. At that time, the appealing to the reversion of the middle class became the major objective to maintain the healthy development of cities. Therefore, the social objectives of Garden City were reflected throughout the community designs of the garden cities, which advocated the harmonious development between the society and the nature, a reasonable density, affordable residences which could be accepted by each family, and the community residents 
who could enjoy independence. In the specific design concepts, Garden City, on the one hand, offered the detailed zoning and boundary in the urban functions, emphasized the importance of the urban system, and limited the suburban sprawl by reasonably using the multilayer layout of a central city with satellite towns and the strict land sizes. On the other hand, it outlined a layout with harmony between the society and the nature; it also created the mutual coordination between work places and public spaces by building gardens around the central city, using wide traffic connection between the central city and satellite towns, and setting greenbelts and public facilities along the transportation axis. On the whole, Garden City brought up an overall social urban planning mode which was fair, interconnected and self-sufficient. [8]

Garden City has been prospering in a century long period because, as it successful defined the urban problems by using the values of local communities. In the meanwhile, it provided the government with specific strategies which met the needs of economic development and achieved goals of the management from a wide range of social and political visions. [9] Garden City was the first compact design concept aiming at the urban sprawl and the suburbanized transformation, of which the design of landscape and places adopted the values reflecting the community spirits. Therefore, it exerted a great influence on new urbanism later.

\subsection{Neighborhood Units: the Amendment and Update of the Garden City Concepts}

Howard did not explain the functional zoning and the land use modes of the central city and satellite towns in the blueprint of the Garden City, which resulted in the much less operability of the Garden City in practice. The world's first garden city Letchworth was built based on the designer's reference to other trends of thoughts and cultural values, so the original intension of Garden City was practically cast off. Therefore, Garden City was gradually replaced by the Garden Suburbanization concepts which became a new trend in the development of suburbs. Neighborhood Units was one of it.

In 1930s, Perry (1930) discussed in detail about the functional layout of the community and the central city which was never involved in the Garden City concepts. He put forward the "Neighborhood Units" theory to adapt to the development of the urban motor transportation in attempt to redesign the layout of the residential areas at the center and at the edge of the city. With a continuation of the compact layout concept of Garden City, it advocated the mixed use of land, construction of public spaces and harmonious neighborhood relationships. It focused on the construction of public facilities in the community, called for the school-centered community construction mode, promoted the development of public spaces linked by the neighborhood relationship, and enhanced the social justice and the class integration [10]. In this way it not only greatly amended and updated the deficiencies of the traditional Garden City concepts, but also provided the ideological foundation for new urbanism thought. In 1940s and 1950s, the design concept of Neighborhood Units was popular for some time, but it was proved in practice that the implementation of both Garden City and Neighborhood Units failed to effectively put the suburbanization and the urban sprawl under control. Instead, they accelerated the urban expansion in the spatial regions.

\subsection{Traditional Neighborhood Design ( TND ) : the Commencement of New Urbanism}

Although the concepts of Garden City and Neighborhood Units had countless ties with new urbanism thoughts, the theoretical circle officially regarded the emergence of the Traditional Neighborhood Development as the commencement of new urbanism. This design was brought up by Duany (2000), a well-known representative of new urbanism. The basic principle of the design was to assume that a clear and closed space would bring comfort to the residents in the community, so more attention was paid to the space design of the community and the city center. TND often regarded the city center with commerce, municipality and mixed residence as the sign of community and the core of social contacts; squares and greenbelts were used to create public spaces and places; the residential complex with the medium building density and the low-rise buildings were adopted to enhance the social contacts in the community; narrow streets were taken to adjust layout of garages, limit driving speed and enhance the pedestrian possibilities; emphases were given to the visual 
consistency of economic grade residences and top grade ones.[11] TND designers believed that the reconstruction of living environment and the architectural scenes could promote the integration of the community and create a good social order. However, as the high quality of the space design needed a large number of financial and human resources, the ideas of TND designers were often difficult to achieve by the market mechanism. The economic residence often became a costly luxury, which was still a nightmare for poor families. As a result, the social division still existed.

\subsection{Transit-oriented Development (TOD) and City Villages: Expansion of New Urbanism}

TOD and City Villages, another two modes of new urbanism thoughts, have the basic features of new urbanism concepts with different focuses. TOD focuses on the impact of the design of the transportation means on the urban spaces and land uses while City Villages on the design of streets and communities. Calthorpe (1993) and Kelbaugh (1989), the TOD advocators, argues that the transportation manner exerts a more direct impact on the community or urban residents and the regional mode of transportation has an important impact on the spatial forms of the city [12-13]. Therefore, the design of the TOD seeks to limit the use of private cars by using the public transportation and the stop design to change the utilization mode of zones and land. With the mixed methods, it uses the land near the transit hubs differently as commercial centers, pedestrian streets and work places. The networking transit hub is taken as the center to divide the clear peripheral zones so as to form the scattered pattern from the center with the low residential density to the edges with the high residential density. The transit hub is taken as the center to determine the boundary of the urban growth and the clear scope of the public space.

The City Villages is different in that it not only includes more TND principles and the Neighborhood Units concepts, but also absorbs many TOD designs, so it can be regarded as the typical example of references and mixture within new urbanism frames. As another mode of new urbanism, City Villages focuses on the compact design layout, mixed land use and residential complex. It can either follow the TND principles to create the community landscape or use the TOD principles to conduct the infill development. Therefore, it has a high flexibility. The design of City Villages is characterized by self-sufficiency, harmonious neighborhood relationship, sufficient public spaces and compact layouts. In general, City Villages needs to have a central square, greenbelts, and streets mainly for pedestrians, mixed uses of land, well-developed transportation networks, commercial centers, schools, places of employment, and other supporting public facilities. Owing to the compact layouts and the mixed residences, City Villages requires the residential areas to be near the employment places, public facilities, schools and commercial centers so as to form a reasonably distributed spatial mode. Meanwhile, City Villages requires a high proportion of economic and public residences, which are a strong guarantee to promote social contacts and eliminate the class isolation.

\subsection{Smart Growth: Sublimation of New Urbanism Theories}

After thirty years of evolution and management, new urbanism thoughts are mostly known for their practices. However, their theoretical construction and elaboration are not in-depth enough. The representative figures of new urbanism generally agree that theories are the best means to publicize the values of new urbanism, but planners never make designs in full accordance with the theories, nor do they care about the value of promoting good designs to the theories. [14] As a result, since 1990s, new urbanism has started the theoretical construction in order to obtain the support from politicians and the public, which gave birth to the theory of Smart Growth.

No matter whether it is to realize the designers' personal values or the social expectations, the concepts of new urbanism are established on the basis of urban development. Without the urban growth and the sustainable development, everything should become a fantasy. When it happened that the public strongly resisted a series of urban problems caused by the overexpansion of the city in 1990s, the Smart Growth proposal was accepted by politicians and the public very quickly. In a short time, the thought spread out. The theory of Smart Growth pointed out that the major problems of urban growth after World War II were caused by the improper growth management. It was because the 
government adopted the growth management policies of the strict control and partition planning that led to the urban sprawl, recession in downtown areas, overlong commuting distances and high prices of residence. Therefore, Smart Growth advocated the new regional planning, allowed the cities and towns to plan their growth in wider scopes, reduced the negative external pressures by reasonable uses of existing infrastructure, and called for public policies to intervene in the development and management. At the same time, it reiterated the so-called "compact, mixed, diversified, pedestrian-oriented, and differentiating the center from edges" principles of New urbanism. So far, Smart Growth has been feasible in the free market system, for it has encouraged the development and access of private sectors to a large extent. [15]

\begin{tabular}{|c|c|c|c|c|}
\hline Thoughts & Determined Problems & Major Concepts & Resolutions & Fate of the Thoughts \\
\hline Garden City & $\begin{array}{l}\text { Sprawl, over-sized } \\
\text { cities, separated from } \\
\text { the nature, expensive } \\
\text { residences, and poor } \\
\text { conditions }\end{array}$ & $\begin{array}{l}\text { Equal, beautiful, } \\
\text { sanitary, family, } \\
\text { community, } \\
\text { nature, and } \\
\text { country life }\end{array}$ & $\begin{array}{l}\text { Developing cheap } \\
\text { lands, controlling the } \\
\text { growth, limiting the } \\
\text { density, simulating } \\
\text { nature, and separating } \\
\text { functions }\end{array}$ & $\begin{array}{l}\text { Dominating mode in } \\
\text { the } 20^{\text {th }} \text { century, } \\
\text { gradually simplified } \\
\text { and evolved as the } \\
\text { suburb mode }\end{array}$ \\
\hline $\begin{array}{l}\text { Neighborho } \\
\text { od Units }\end{array}$ & $\begin{array}{c}\text { Auto/pedestrian } \\
\text { selection, lack of signs, } \\
\text { lack of communities }\end{array}$ & $\begin{array}{c}\text { Beautiful, } \\
\text { family, effective, } \\
\text { community }\end{array}$ & $\begin{array}{c}\text { Traffic separation, } \\
\text { functional separation, } \\
\text { layouts centered at } \\
\text { schools }\end{array}$ & $\begin{array}{c}\text { Popular since 1930s, } \\
\text { and integrated to } \\
\text { Garden City }\end{array}$ \\
\hline $\begin{array}{c}\text { School of } \\
\text { Revisionism }\end{array}$ & $\begin{array}{l}\text { Sprawl, retro, layers, } \\
\text { degradation, confusion }\end{array}$ & $\begin{array}{l}\text { Technology, } \\
\text { equal, effective, } \\
\text { civilization, } \\
\text { functionalism }\end{array}$ & $\begin{array}{l}\text { High buildings, high } \\
\text { density, functional } \\
\text { separation, multilayer } \\
\text { layout of roads }\end{array}$ & $\begin{array}{l}\text { Popular in urban } \\
\text { centers and public } \\
\text { residences, and } \\
\text { integrated to Garden } \\
\text { City at the later stage }\end{array}$ \\
\hline TND/TOD & $\begin{array}{c}\text { Sprawl, auto-oriented } \\
\text { development, } \\
\text { ugly-looking }\end{array}$ & $\begin{array}{l}\text { Beautiful, equal, } \\
\text { pedestrian, } \\
\text { community, } \\
\text { tradition }\end{array}$ & $\begin{array}{c}\text { Mixed uses, increasing } \\
\text { density, residential } \\
\text { complex, urban signs, } \\
\text { transformed square } \\
\text { layout }\end{array}$ & $\begin{array}{l}\text { The new ideal adopted } \\
\text { at the end of } 20^{\text {th }} \\
\text { century, popular in } \\
\text { some countries, and } \\
\text { belonging to New } \\
\text { urbanism }\end{array}$ \\
\hline $\begin{array}{c}\text { City } \\
\text { Villages }\end{array}$ & $\begin{array}{l}\text { Lack of places and } \\
\text { signs, and lack of } \\
\text { economic residence in } \\
\text { communities }\end{array}$ & $\begin{array}{l}\text { Civilized, } \\
\text { beautiful, equal, } \\
\text { pedestrian, } \\
\text { community, } \\
\text { tradition, country } \\
\text { life } \\
\end{array}$ & $\begin{array}{l}\text { Traditional classic } \\
\text { architectures, mixed } \\
\text { uses, density, } \\
\text { residential complex, } \\
\text { village standards, and } \\
\text { local styles }\end{array}$ & $\begin{array}{l}\text { Economic residences } \\
\text { are hard to realize, } \\
\text { designed areas are } \\
\text { faced with reduction, } \\
\text { and it is integrated to } \\
\text { New urbanism }\end{array}$ \\
\hline $\begin{array}{l}\text { Smart } \\
\text { Growth }\end{array}$ & $\begin{array}{l}\text { Sprawl, recession, high } \\
\text { price of residence, and } \\
\text { auto-oriented }\end{array}$ & $\begin{array}{l}\text { Equal, limited, } \\
\text { and government } \\
\text { intervention }\end{array}$ & $\begin{array}{l}\text { Mixed uses, increasing } \\
\text { density, residential } \\
\text { complex, regional } \\
\text { planning, and public } \\
\text { policies } \\
\end{array}$ & $\begin{array}{l}\text { Popular in the free } \\
\text { market mechanism }\end{array}$ \\
\hline
\end{tabular}

Table 1: The History and Features of New Urbanism Thoughts

\section{Conclusion}

After the long evolution and improved management, new urbanism has gradually become a mature urban planning concept and prevailed in many countries in the world. The emergence of new urbanism, to some extent, reflects the needs of the government and the public to iron out the disorder of the urban space and the suburbanized sprawl. However, the developing direction of new urbanism thoughts in the future is still unclear to us.

Acknowledgment: Sponsored by the Fundamental Research Funds for the Central Universities (No.SWJTU12CX123) and by the Creation Group led by Ms. Chen Youzhen in School of Public Administration, Southwest Jiaotong University. 


\section{References}

[1] CHU Jing; WANG Xing-zhong. The Community Fragmentation and Governance of Metropolitan Suburbanization [J].World Regional Studies.2011, 20(1):96-97

[2]Lock D. Room for more within city limits? [J].Town and Country Planning.1991, 60(11):337-339

[3]Dunlop B. The new urbanisms: the second generation [J].Architectural Record.1997, 97(1):132-134

[4] Kevin L.Good City Form [M].BeiJing: Hua Xia Press.2001:36-40

[5] Jacobs J. Death and Life of Great American Cities [M].New York: Vintage Books: 6-21

[6] Grant J. Mixed use in theory and practice: Canadian experience with implementing a planning principle [J].Journal of the American Planning Association.2002, 68(1):71-84

[7] Neuman J. Building in affordability [J].Urban Land.2003, 62(5):64-65
[8] Ward S. The Garden City: Past, present and future [M].London: E\&FN Spon: 31-35

[9] Mitchell J G. Urban sprawl [J].National Geographic.2001, 200(1):48-73

[10] Perry C. The neighborhood unit [J].Neighborhood and Community Planning.1974, (7):3-16

[11]Duany A, Talen E. Transent planning [J]. Journal of American Planning Association.2002, 68(3):245-266

[12] Calthorpe P. The Next American Metropolis [M].New York: Princeton Architectural Press: 278-284

[13] Kelbaugh D. The Pedestrian Pocket Book: A new suburban design strategy $[\mathrm{M}]$.New York: Princeton Architectural Press: 178-189

[14] Milgrom R. Engaging new urbanism [J].Planner Network.2002, 151(2):9

[15] CAI Xiaobo. "Smart Growth"and Its Inspiration to Domestic Urban Planning and Management [J]. Tropical Geography, 2010, 30 (1):84-86 